\title{
Radiosurgery for recurrent glioblastoma: a review article
}

\author{
Ferrat Dincoglan, Omer Sager*, Selcuk Demiral, Bora Uysal, Hakan Gamsiz, Bahar Dirican and Murat Beyzadeoglu \\ Department of Radiation Oncology, University of Health Sciences, Gulhane Medical Faculty, Ankara, Turkey
}

\begin{abstract}
Glioblastoma (GB) is the most common primary brain tumor in adults, accounting for more than half of all diffuse gliomas with an agressive disease course despite multimodality management. Too few patients with GB live more than 5 years, and there are several prognostic factors including age, performance status, and MGMT promoter methylation which is associated with response to Temozolomide treatment. Standard of care in newly diagnosed GB has been established in 2005 as concurrent chemoradiotherapy, based on the landmark European Organisation for Research and Treatment of Cancer (EORTC)/National Cancer Institute of Canada Clinical Trials Group (NCIC-CTG) study demonstrating a clinically meaningful and significant median overall survival benefit with the addition of Temozolomide to conventionally fractionated partial brain radiotherapy. However, recurrence is very common in an overwhelming majority of the patients with a grim prognosis. Several therapeutic strategies are employed in the recurrent setting with no established standard of care. Reoperation, repeat radiotherapy, chemotherapy, tumor treating fields, antiangiogenic and other targeted agents, experimental treatments and combinations of modalities have been used for management of patients with recurrent GB depending on tumor and patient characteristics. Herein, we review the use of radiosurgery for management of recurrent GB in light of the literature.
\end{abstract}

\section{Introduction}

Glioblastoma (GB) is the most common primary brain tumor in adults, accounting for more than half of all diffuse gliomas with an agressive disease course despite multimodality management [1]. Too few patients with GB live more than 5 years, and there are several prognostic factors including age, performance status, and MGMT promoter methylation which is associated with response to Temozolomide treatment [2-5].

Standard of care in newly diagnosed GB has been established in 2005 as concurrent chemoradiotherapy, based on the landmark European Organisation for Research and Treatment of Cancer (EORTC)/ National Cancer Institute of Canada Clinical Trials Group (NCICCTG) study demonstrating a clinically meaningful and significant median overall survival benefit with the addition of Temozolomide to conventionally fractionated partial brain radiotherapy [6]. However, recurrence is very common in an overwhelming majority of the patients with a grim prognosis. Several therapeutic strategies are employed in the recurrent setting with no established standard of care. Reoperation, repeat radiotherapy, chemotherapy, tumor treating fields, antiangiogenic and other targeted agents, experimental treatments and combinations of modalities have been used for management of patients with recurrent GB depending on tumor and patient characteristics. Treatment at the recurrent setting is typically more complex due to already received previous treatments at the initial diagnosis along with the diffusely infiltrating nature of the disease following an aggressive course with a rapid proliferative rate. Repeat surgery may be hampered by involvement of the eloquent cortex in an infiltrative manner with an increased risk of complications in the recurrent disease setting. Nevertheless, surgery may be particularly useful for relieving symptoms of the mass effect in selected patients with recurrent disease located in a non-eloquent brain region, and the extent of surgical removal of the recurrent GB lesion may impact overall survival [7,8]. Also, establishing the accurate diagnosis with confirmation of the initial histology may be achieved by surgery along with detection of molecular markers for potential therapeutic exploitation [9]. Herein, we review the use of radiosurgery for management of recurrent GB in light of the literature.

\section{Radiosurgery for recurrent glioblastoma}

Given the advances in the discipline of radiation oncology, precisely focused stereotactic irradiation in a contemporary fashion has been widely accepted in management of several benign and malign conditions with considerable success [10-25]. In the context of recurrent GB, several reports have assessed the role of radiosurgery delivered either in a single session or in a hypofractionated manner with or without integration of other agents [7,9,11,25,26-52].

The utility of salvage radiotherapy in recurrent GB management has dramatically expanded with the incorporation of radiosurgery in the radiotherapeutic armamentarium. Improved spatial target localization by virtue of advanced neuroimaging techniques allows for precisely focused delivery of high effective target doses with optimal normal tissue sparing through steep dose gradients achieved via robust stereotactic localization and intensity-modulated computerized treatment planning for accurate radiosurgery applications $[53,54]$.

\section{Rationale for radiosurgery}

High effective radiation doses delivered in a limited number of treatment fractions lead to enhanced killing of malignant cells with diminished tumor repopulation, and the tumoricidal effect of

Correspondence to: Omer Sager, MD, Associate Professor, University of Health Sciences, Gulhane Medical Faculty, Department of Radiation Oncology, Gn.Tevfik Saglam Cad. 06018, Etlik, Kecioren Ankara/TURKEY. Tel: +90 312 304 4683, E-mail: omersager@gmail.com

Key words: recurrent glioblastoma (GB), stereotactic radiosurgery (SRS), hypofractionated stereotactic radiotherapy (HFSRT), radiosurgery

Received: September 30, 2017; Accepted: October 23, 2017; Published: October 26,2017 
radiosurgery may be accomplished through DNA injury, induced apoptosis and vascular endothelial damage $[55,56]$.

In terms of patient convenience, radiosurgery with a condensed radiation treatment schedule provides shortening of overall radiotherapy time and recovery as an outpatient procedure resulting in improved patient compliance. As the applications of radiosurgery expanded, there has been a rapid incorporation of innovative technologies improving treatment precision with decreased costs, and radiosurgery beginned serving as a very favorable and affordable radiotherapeutic strategy comprising an indespensable part of both neurosurgery and radiation oncology practice [57].

\section{Outcomes of radiosurgery}

Overall, studies of radiosurgery for recurrent GB suggest a moderate therapeutic benefit with an improved toxicity profile and the reported survival rates are promising at the least if not better compared to other salvage treatment options. Clearly, vigilance is required for patient selection in the salvage treatment setting since any therapeutic intervention may induce morbidity with substantial burden on the patients typically exhausted with the previous treatments. In this respect, a multidisciplinary approach is warranted with thorough consideration of several factors including age, performance status, time interval from initial surgery and radiotherapy, tumor location and volume, MGMT promoter methylation status, extent of surgery, details of initial radiotherapy, patient preference and quality-oflife. Nevertheless, salvage management of patients with recurrent GB should be strongly considered given the relentless disease course without treatment and improved toxicity profile of contemporary treatments with low adverse effect on patients' quality-of-life. [27,28].

Radiosurgery may be a viable radiotherapeutic alternative for management of recurrent GB patients with high performance status, young age, and small tumor size appropriate for focused irradiation. [9,45,58,59-61]. Figure 1 shows radiosurgery treatment planning images of a patient with recurrent GB.

\section{Future perspectives and conclusion}

Attempts to improve radiosurgical outcomes for recurrent GB management include the addition of antiangiogenic agents, which may have a potential role in improving the toxicity profile through decreased radiation necrosis along with normalization of tumor vasculature providing potentially enhanced radiotherapeutic activity due to increased oxygenation. [26,41,61].

In conclusion, radiosurgery offers a viable non-invasive treatment strategy for patients with recurrent GB. Comparison of different therapeutic modalities is confounded by diverse patient and treatment characteristics, however, randomized controlled trials may shed light on optimal management of recurrent GB. The utility of radiosurgery has expanded thanks to recent advances in technology and improvements in neuroimaging, radiosurgery techniques, equipment, treatment planning and delivery systems. Incorporation of antiangiogenic and other agents may improve outcomes of radiosurgery despite the need for further studies.

\section{Conflict of interest}

There is no conflict of interest.

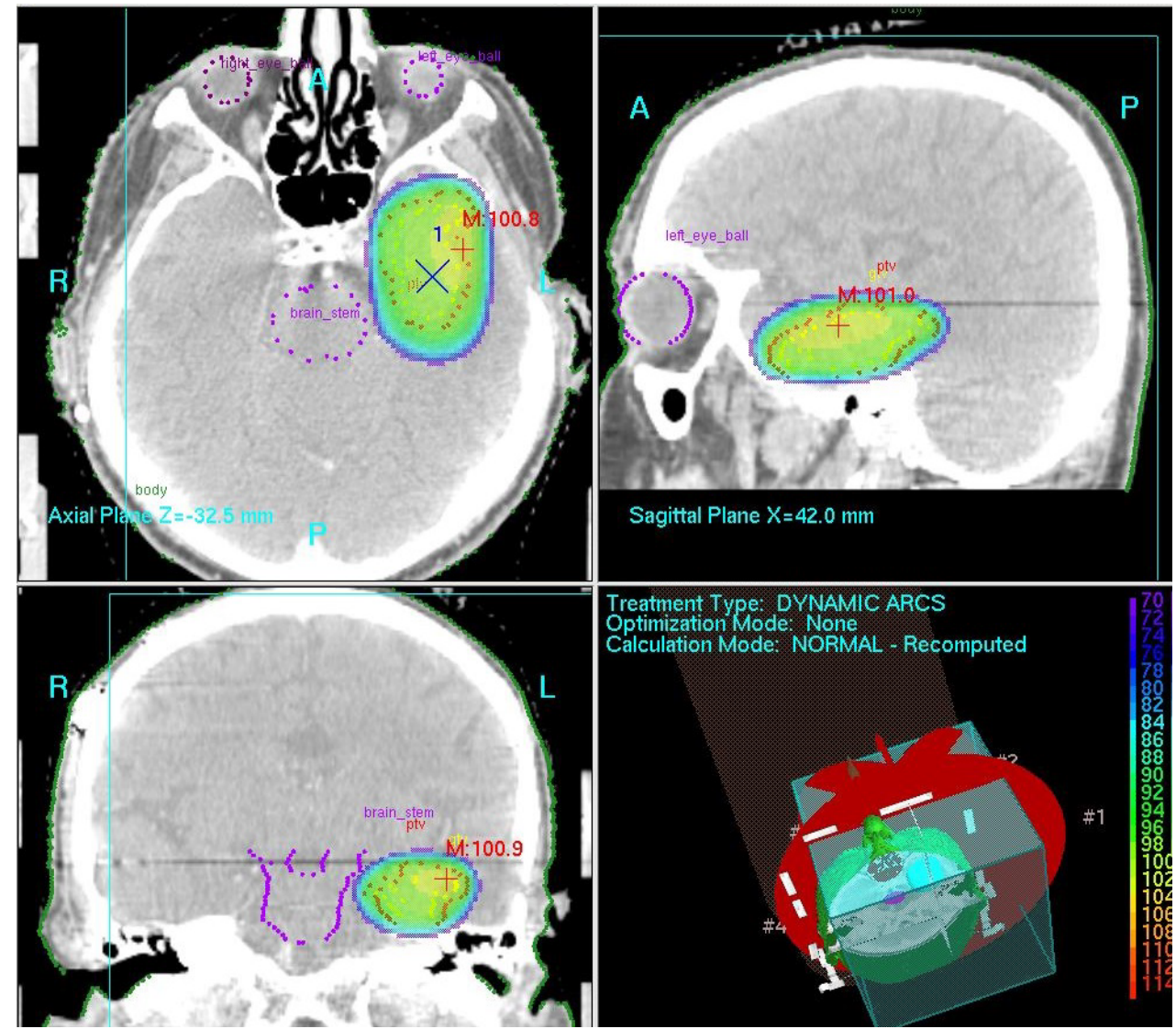

Figure 1. Radiosurgery treatment planning images of a patient with recurrent GB 


\section{References}

1. Ostrom QT, Gittleman H, Xu J, Kromer C, Wolinsky Y, et al. (2016) CBTRUS Statistical Report: Primary Brain and Other Central Nervous System Tumors Diagnosed in the United States in 2009-2013. Neuro Oncol 18: v1-v75. [Crossref]

2. Yang F, Yang P, Zhang C, Wang Y, Zhang W, et al. (2017) Stratification according to recursive partitioning analysis predicts outcome in newly diagnosed glioblastomas. Oncotarget 8: 42974-42982. [Crossref]

3. Nakagawa Y, Sasaki H2, Ohara K3, Ezaki T1, Toda M1, et al. (2017) Clinical and Molecular Prognostic Factors for Long-Term Survival of Patients with Glioblastomas in Single-Institutional Consecutive Cohort. World Neurosurg 106: 165-173. [Crossref]

4. Hegi ME1, Diserens AC, Gorlia T, Hamou MF, de Tribolet N, et al. (2005) MGMT gene silencing and benefit from temozolomide in glioblastoma. $N$ Engl J Med 352: 997-1003. [Crossref]

5. Curran WJ Jr, Scott CB, Horton J, Nelson JS, Weinstein AS, et al. (1993) Recursive partitioning analysis of prognostic factors in three Radiation Therapy Oncology Group malignant glioma trials. J Natl Cancer Inst 85: 704-710. [Crossref]

6. Stupp R, Mason WP, van den Bent MJ, Weller M, Fisher B, et al. (2005) Radiotherapy plus concomitant and adjuvant temozolomide for glioblastoma. $N$ Engl J Med 352: 987-996. [Crossref]

7. Kirkpatrick JP, Sampson JH (2014) Recurrent malignant gliomas. Semin Radiat Oncol 24: 289-298. [Crossref]

8. Bloch O, Han SJ, Cha S, Sun MZ, Aghi MK, et al. (2012) Impact of extent of resection for recurrent glioblastoma on overall survival: clinical article. J Neurosurg 117: 10321038. [Crossref]

9. Seystahl K, Wick W, Weller M (2016) Therapeutic options in recurrent glioblastoma-An update. Crit Rev Oncol Hematol 99: 389-408. [Crossref]

10. Demiral S, Dincoglan F, Sager O, Gamsiz H, Uysal B, et al. (2016) Hypofractionated stereotactic radiotherapy (HFSRT) for who grade I anterior clinoid meningiomas (ACM). Jpn J Radiol 34: 730-737. [Crossref]

11. Dincoglan F, Beyzadeoglu M, Sager O, Demiral S, Gamsiz H, et al. (2015) Management of patients with recurrent glioblastoma using hypofractionated stereotactic radiotherapy. Tumori 101: 179-184. [Crossref]

12. Sager O, Dincoglan F, Beyzadeoglu M (2015) Stereotactic radiosurgery of glomus jugulare tumors: current concepts, recent advances and future perspectives. CNS Oncol 4: 105-114. [Crossref]

13. Gamsiz H, Beyzadeoglu M, Sager O, Demiral S, Dincoglan F, et al. (2015) Evaluation of stereotactic body radiation therapy in the management of adrenal metastases from non-small cell lung cancer. Tumori 101: 98-103. [Crossref]

14. Dincoglan F, Sager O, Gamsiz H, Uysal B, Demiral S, et al. (2014) Management of patients with $\geq 4$ brain metastases using stereotactic radiosurgery boost after whole brain irradiation. Tumori 100: 302-306. [Crossref]

15. Demiral S, Beyzadeoglu M, Sager O, Dincoglan F, Gamsiz H, et al. (2014) Evaluation of linear accelerator (linac)-based stereotactic radiosurgery (srs) for the treatment of craniopharyngiomas. UHOD - Uluslararasi Hematoloji-Onkoloji Dergisi 24: 123-129.

16. Sager O, Beyzadeoglu M, Dincoglan F, Gamsiz H, Demiral S, et al. (2014) Evaluation of linear accelerator-based stereotactic radiosurgery in the management of glomus jugulare tumors. Tumori 100: 184-188. [Crossref]

17. Gamsiz H, Beyzadeoglu M, Sager O, Dincoglan F, Demiral S, et al. (2014) Management of pulmonary oligometastases by stereotactic body radiotherapy. Tumori 100: 179-183. [Crossref]

18. Sager O, Beyzadeoglu M, Dincoglan F, Uysal B, Gamsiz H, et al. (2014) Evaluation of linear accelerator (LINAC)-based stereotactic radiosurgery (SRS) for cerebral cavernous malformations: a 15-year single-center experience. Ann Saudi Med 34: 5458. [Crossref]

19. Sager O, Beyzadeoglu M, Dincoglan F, Demiral S, Uysal B, et al. (2013) Management of vestibular schwannomas with linear accelerator-based stereotactic radiosurgery: a single center experience.Tumori 99: 617-622. [Crossref]

20. Dincoglan F, Beyzadeoglu M, Sager O, Uysal B, Demiral S, et al. (2013) Evaluation of linear accelerator-based stereotactic radiosurgery in the management of meningiomas: a single center experience. J BUON 18: 717-722. [Crossref]

21. Demiral S, Beyzadeoglu M, Uysal B, Oysul K, Kahya YE, et al. (2013) Evaluation of stereotactic body radiotherapy (SBRT) boost in the management of endometrial cancer. Neoplasma 60: 322-327. [Crossref]
22. Surenkok S, Sager O, Dincoglan F, Gamsiz H, Demiral S, et al. (2012) Stereotactic radiosurgery in pituitary adenomas: a single center experience. UHOD - Uluslararasi Hematoloji-Onkoloji Dergisi 22: 255-260.

23. Dincoglan F, Sager O, Gamsiz H, Demiral S, Uysal B, et al. (2012) Management of arteriovenous malformations by stereotactic radiosurgery: a single center experience. UHOD - Uluslararasi Hematoloji-Onkoloji Dergisi 22: 107-112.

24. Dincoglan F, Beyzadeoglu M, Sager O, Oysul K, Sirin S, et al. (2012) Image-guided positioning in intracranial non-invasive stereotactic radiosurgery for the treatment of brain metastasis. Tumori 98: 630-635. [Crossref]

25. Sirin S, Oysul K, Surenkok S, Sager O, Dincoglan F, et al. (2011) Linear acceleratorbased stereotactic radiosurgery in recurrent glioblastoma: a single center experience. Vojnosanit Pregl 68: 961-966. [Crossref]

26. Clarke J, Neil E, Terziev R, Gutin P, Barani I, et al. (2017) Multicenter, Phase 1, Dose Escalation Study of Hypofractionated Stereotactic Radiation TherapyWith Bevacizumab for Recurrent Glioblastoma and Anaplastic Astrocytoma. Int J Radiat Oncol Biol Phys pii: S0360-3016: 33549-33556. [Crossref]

27. Prabhu VC1, Barton KP2, Walsh S3, Borys E4, Melian E5 (2017) Recurrent Malignan Gliomas: Treatment Options and Their Effect on Patient's Quality of Life. World Neurosurg 103: 906-910. [Crossref]

28. Stöckelmaier L, Renovanz M, König J, Nickel K, Hickmann AK, et al. (2017) Therapy for Recurrent High-Grade Gliomas: Results of a Prospective Multicenter Study on Health-Related Quality of Life. World Neurosurg 102: 383-399. [Crossref]

29. Cabrera AR, Kirkpatrick JP, Fiveash JB, Shih HA, Koay EJ, et al. (2016) Radiation therapy for glioblastoma: Executive summary of an American Society for RadiationOncology Evidence-Based Clinical Practice Guideline. Pract Radiat Oncol 6: 217-225. [Crossref]

30. Nieder C, Andratschke NH, Grosu AL (2016) Re-irradiation for Recurrent Primary Brain Tumors. Anticancer Res 36: 4985-4995. [Crossref]

31. Minniti G, Agolli L, Falco T, Scaringi C, Lanzetta G, et al. (2015) Hypofractionated stereotactic radiotherapy in combination with bevacizumab or fotemustine for patients with progressive malignant gliomas. $J$ Neurooncol 122: 559-566. [Crossref]

32. Wuthrick EJ, Curran WJ Jr, Camphausen K, Lin A, Glass J, et al. (2014) A pilot study of hypofractionated stereotactic radiation therapy and sunitinib in previouslyirradiated patients with recurrent high-grade glioma. Int J Radiat Oncol Biol Phys 90: 369-375. [Crossref]

33. Yazici G, Cengiz M, Ozyigit G, Eren G, Yildiz F, et al. (2014) Hypofractionated stereotactic reirradiation for recurrent glioblastoma. J Neurooncol 120: 117-123. [Crossref]

34. Sheehan JP, Lee CC2 (2014) Stereotactic radiosurgery for recurrent high-grade gliomas. World Neurosurg 82: e593-595. [Crossref]

35. Anand AK, Kumar P, Patir R, Vaishya S, Bansal AK, et al. (2014) Fractionated stereotactic radiosurgery with volumetric modulated arc therapy (Rapid Arc) for reradiation in recurrent high grade gliomas. J Cancer Res Ther 10: 97-102. [Crossref]

36. Martínez-Carrillo M, Tovar-Martín I, Zurita-Herrera M, Del Moral-Ávila R, GuerreroTejada R, et al. (2014) Salvage radiosurgery for selected patients with recurrent malignant gliomas. Biomed Res Int 2014: 657953.

37. Ciammella P, Podgornii A, Galeandro M, D'Abbiero N, Pisanello A, et al. (2013) Hypofractionated stereotactic radiation therapy for recurrent glioblastoma: single institutional experience. Radiat Oncol 8: 222. [Crossref]

38. McKenzie JT, Guarnaschelli JN, Vagal AS, Warnick RE, Breneman JC (2013) Hypofractionated stereotactic radiotherapy for unifocal and multifocal recurrence of malignant gliomas. J Neurooncol 113: 403-409.

39. Minniti G, Scaringi C, De Sanctis V, Lanzetta G, Falco T, et al. (2013) Hypofractionated stereotactic radiotherapy and continuous low-dose temozolomide in patientswith recurrent or progressive malignant gliomas. J Neurooncol 111: 187-194. [Crossref]

40. Ogura K, Mizowaki T, Arakawa Y, Sakanaka K, Miyamoto S, et al. (2013) Efficacy of salvage stereotactic radiotherapy for recurrent glioma: impact of tumor morphologyand method of target delineation on local control. Cancer Med 2: 942-949. [Crossref]

41. Cuneo KC, Vredenburgh JJ, Sampson JH, Reardon DA, Desjardins A, et al. (2012) Safety and efficacy of stereotactic radiosurgery and adjuvant bevacizumab in patients with recurrent malignant gliomas. Int J Radiat Oncol Biol Phys 82: 2018-2024. [Crossref]

42. Skeie BS, Enger PØ, Brøgger J, Ganz JC, Thorsen F, et al. (2012) $\gamma$ knife surgery versus reoperation for recurrent glioblastoma multiforme. World Neurosurg 78: 658669. [Crossref] 
43. Conti A, Pontoriero A, Arpa D, Siragusa C, Tomasello C, et al. (2012) Efficacy and toxicity of CyberKnife re-irradiation and "dose dense" temozolomide for recurrent gliomas. Acta Neurochir (Wien) 154: 203-209. [Crossref]

44. Maranzano E, Anselmo P, Casale M, Trippa F, Carletti S, et al. (2011) Treatment of recurrent glioblastoma with stereotactic radiotherapy: long-term results of a monoinstitutional trial. Tumori 97: 56-61. [Crossref]

45. Fogh SE, Andrews DW, Glass J, Curran W, Glass C, et al. (2010) Hypofractionated stereotactic radiation therapy: an effective therapy for recurrent high-grade gliomas. $J$ Clin Oncol 28: 3048-3053. [Crossref]

46. Fokas E, Wacker U, Gross MW, Henzel M, Encheva E, et al. (2009) Hypofractionated stereotactic reirradiation of recurrent glioblastomas : a beneficial treatment option after high-dose radiotherapy? Strahlenther Onkol 185: 235-240. [Crossref]

47. Patel M, Siddiqui F, Jin JY, Mikkelsen T, Rosenblum M, et al. (2009) Salvage reirradiation for recurrent glioblastoma with radiosurgery: radiographic response and improved survival. J Neurooncol 92: 185-191. [Crossref]

48. Henke G, Paulsen F, Steinbach JP, Ganswindt U, Isijanov H, et al. (2009) Hypofractionated reirradiation for recurrent malignant glioma. Strahlenther Onkol 185: 113-119. [Crossref]

49. Schwer AL, Kavanagh BD, McCammon R, Gaspar LE, Kleinschmidt-De Masters BK, et al. (2008) Radiographic and histopathologic observations after combined EGFR inhibition and hypofractionated stereotactic radiosurgery in patients with recurrent malignant gliomas. Int J Radiat Oncol Biol Phys 73: 1352-1357. [Crossref]

50. Vordermark D , Kölbl O, Ruprecht K, Vince GH, Bratengeier K,et al. (2005) Hypofractionated stereotactic re-irradiation: treatment option in recurrent malignant glioma. BMC Cancer 5: 55. [Crossref]

51. Grosu AL, Weber WA, Franz M, Stärk S, Piert M, et al. (2005) Reirradiation of recurrent high-grade gliomas using amino acid PET (SPECT)/CT/MRI imagefusion to determine gross tumor volume for stereotactic fractionated radiotherapy. Int J Radiat Oncol Biol Phys 63: 511-519. [Crossref]
52. Shepherd SF, Laing RW, Cosgrove VP, Warrington AP, Hines F, et al. (1997) Hypofractionated stereotactic radiotherapy in the management of recurrent glioma. Int J Radiat Oncol Biol Phys 37: 393-398. [Crossref]

53. Levivier M, Gevaert T, Negretti L (2011) Gamma Knife, CyberKnife, TomoTherapy: gadgets or useful tools? Curr Opin Neurol 24: 616-625. [Crossref]

54. Vesper J, Bölke B, Wille C, Gerber PA, Matuschek C, et al. (2009) Current concepts in stereotactic radiosurgery - a neurosurgical and radiooncological point of view. Eur J Med Res 14: 93-101. [Crossref]

55. Balagamwala EH, Chao ST, Suh JH (2012) Principles of radiobiology of stereotactic radiosurgery and clinical applications in the central nervous system. Technol Cancer Res Treat 11: 3-13. [Crossref]

56. Larson DA, Flickinger JC, Loeffler JS (1993) The radiobiology of radiosurgery. Int J Radiat Oncol Biol Phys 25: 557-561. [Crossref]

57. Niranjan A, Madhavan R, Gerszten PC, Lunsford LD (2012) Intracranial radiosurgery: an effective and disruptive innovation in neurosurgery. Stereotact Funct Neurosurg 90: 1-7. [Crossref]

58. Ryu S, Buatti JM, Morris A, Kalkanis SN, Ryken TC, et al. (2014) The role of radiotherapy in the management of progressive glioblastoma : a systematic reviewand evidence-based clinical practice guideline. J Neurooncol 118: 489-499. [Crossref]

59. Miwa K, Matsuo M, Ogawa S, Shinoda J, Yokoyama K, et al. (2014) Re-irradiation of recurrent glioblastoma multiforme using 11C-methionine PET/CT/MRI imagefusion for hypofractionated stereotactic radiotherapy by intensity modulated radiation therapy. Radiat Oncol 9: 181. [Crossref]

60. Combs SE, Edler L, Rausch R, Welzel T, Wick W, et al. (2013) Generation and validation of a prognostic score to predict outcome after re-irradiation of recurrent glioma. Acta Oncol 52: 147-152. [Crossref]

61. Levin VA, Bidaut L, Hou P, Kumar AJ, Wefel JS, et al. (2011) Randomized doubleblind placebo-controlled trial of bevacizumab therapy for radiation necrosisof the central nervous system. Int J Radiat Oncol Biol Phys 79: 1487-1495. [Crossref]

Copyright: $\odot 2017$ Dincoglan F. This is an open-access article distributed under the terms of the Creative Commons Attribution License, which permits unrestricted use, distribution, and reproduction in any medium, provided the original author and source are credited. 